\title{
sciendo
}

\section{ASSESSMENT OF GENOTYPE BY ENVIRONMENT INTERACTION VIA REACTION NORMS FOR MILK YIELD IN HOLSTEIN CATTLE OF SOUTHERN BRAZIL}

\author{
Henrique Alberto Mulim¹, Luis Fernando Batista Pinto², Aline Zampar³, Gerson Barreto Mourão ${ }^{4}$, \\ Altair Antônio Valloto ${ }^{5}$, Victor Breno Pedrosa ${ }^{1 *}$
}

\author{
${ }^{1}$ Department of Animal Science, State University of Ponta Grossa, General Carlos Cavalcanti Avenue, \\ 4748 - Uvaranas, Ponta Grossa - PR, 84030-900, Brazil \\ ${ }^{2}$ Department of Animal Science, Federal University of Bahia, Adhemar de Barros Avenue, \\ 500 - Ondina, 40170-110, Brazil \\ ${ }^{3}$ Department of Animal Science, State University of Santa Catarina, Beloni Trombeta Zanin Street, \\ 680-E, Santo Antônio, Chapecó - SC, 89815-630, Brazil \\ ${ }^{4}$ Department of Animal Science, University of São Paulo, Jacarandá Mimoso Avenue - Piracicaba - SP, \\ 13400-183, Brazil \\ ${ }^{5}$ Paraná Holstein Breeders Association - APCBRH, Prof. Francisco Dranka Street, 608 - Orleans, \\ Curitiba - PR, 81200-404, Brazil \\ •Corresponding author: vbpedrosa@uepg.br
}

\begin{abstract}
The experiments reported in this research paper were aimed at assessing the genetic responses of a Holstein cow population, as a response to the variations in environmental temperature, through the analysis of the effects resulting from the genotype by environment interaction (GEI), based on reaction norms. Therefore, milk production data was collected from the database of the Paraná Holstein Breeders Association in Brazil for 67,360 primiparous cows born between 1990 and 2015, with the purpose of evaluating the temperature effect, considered as an environmental variable, distinguished under six gradients $\left(17^{\circ} \mathrm{C}\right.$ to $\left.19.5^{\circ} \mathrm{C}\right)$ over the region. A random regression model was adopted, utilizing the fourth order under the Legendre polynomials, applying the mixed models of analysis by the REML method, and using the WOMBAT software. Additionally, the breeding value of the 15 most representative bulls was assessed, in response to the changes in the temperature gradient. The total milk production on average was estimated at $8,412.83 \pm 2,012.08 \mathrm{~kg}$. The heritabilities estimates were found in the low to moderate range, from 0.18 to 0.23 , displaying a decline with a rise in the temperature, highlighting the influence it exerted on the heritabilities. Variations in the genetic expression of some bulls were noted to show differences of up to $289 \mathrm{~kg}$ of milk in response to the increase in the temperature from $17^{\circ} \mathrm{C}$ to $19.5^{\circ} \mathrm{C}$. However, all the genetic correlations between the gradients for milk yield were above 0.80 , in the range of 0.873 to 0.998 , revealing no remarkable interaction between the genotype and environment. This result indicates that the application of the temperature variable in the models of genetic analysis in southern Brazil is not required.
\end{abstract}

Key words: environmental effects, dairy cattle, Legendre polynomials 
From a national perspective, the southern region of Brazil ranks high among the principal milk producers in the country. Although climatic variations are evident in this region, the genetic evaluations applied to date have not considered the temperature differences observed in the distinct regions, which could impact milk production through genotype by environmental interaction (Moreira et al., 2019).

For instance, Al Reyad et al. (2016) and Benni et al. (2020) mentioned about the possible changes in milk production and composition caused by heat stress experienced by animals reared in regions characterized by high temperatures. Moreover, Cotor et al. (2015) confirmed a rise in milk production when animals were subjected to milder temperatures. Thus, temperature appears to affect milk yield in a manner that seems to be linked to the responsible polymorphisms related to the expression of genes that control milk production (Komisarek and Kolenda, 2016).

Although an animal's environment can directly affect milk production and composition, Brazil, which enjoys wide environmental diversity (Moreira et al., 2019), has very few studies related to the influence exerted by each environment type on the genetic variation of the Holstein breed. The present study explores the effects of GEI on milk yield, in an attempt to estimate the performance of the same individual (dam and sire) under different environments while also exploring the interactions between these two factors (Falconer, 1952). The model including GEI represents an extension of the traditional model used for genetic evaluation since it includes the random interactions of the genotype being genetically evaluated as well as the breeding environment, in which the animal is raised (Hammami et al., 2009). This possibility enables the observation of different responses exhibited by the same genotype when exposed to different environments if the existence of GEI is confirmed.

It is evident that genetic and environmental factors, as well as the interactions between them, control economically important traits (Hay and Roberts, 2018); therefore, GEI can become a powerful tool for genetic analysis since the breeding value of animals can be clearly understood as a function of their environment (Dingemanse and Wolf, 2013). The analysis of these interactions has received particular interest among dairy herds since they could influence the estimation of genetic parameters and breeding values when not considered (Streit et al., 2012). Although investments have been made in terms of the genetic selection of dairy herds, few studies have focused on GEI investigations in the country. Such studies will be crucial, as southern Brazil experiences a variety of microclimates, including dry, humid, super-humid or even tropical seasons (SEAB, 2000), which causes a variation in average annual temperatures, from $12^{\circ} \mathrm{C}$ up to $26^{\circ} \mathrm{C}$, depending on the region.

Reaction norm models are the most common approach used to investigate GEI (Tiezzi et al., 2017) and enable the identification of breeding values expressed as a function of an environmental factor (Miranda et al., 2016). Reaction norm models have been largely applied in dairy herds by the many daughters of a single bull exposed to diverse environment types (Rauw and Gomez-Raya, 2015). This facilitates the assessment of different bulls in the range of environments, which these bulls are exposed to as well as animal performance across environmental gradients.

The aims of the present study were to evaluate the necessity of including a genotype by environment interaction effect in the genetic evaluation of milk yield in the 
Holstein cattle of Southern Brazil and analyze the breeding value of the principal bulls in response to changes in temperature gradient within the studied region.

\section{Material and methods}

Using the database of official milk recording from the Paraná Holstein Breeders Association, Brazil (APCBRH), data on adjusted 305-d milk yield from 67,360 primiparous females born between 1990 and 2015 (that were the daughters of 936 bulls) were recorded. The relationship matrix was composed of 95,073 animals belonging to 398 herds from 88 cities in Southern Brazil. This region lies between the parallels $22^{\circ} 30^{\prime} 58^{\prime \prime}$ north latitude and $26^{\circ} 43^{\prime} 00^{\prime \prime}$ south latitude and between the meridians $48^{\circ} 05^{\prime} 37^{\prime \prime}$ east longitude and $54^{\circ} 37^{\prime} 08^{\prime \prime}$ west longitude. It has a territorial area of 199 $307.922 \mathrm{~km}^{2}$, divided into three plateaus, in which $89 \%$ of this area is above 300 meters in height and $52 \%$ is above 600 meters of height (SEAB, 2000).

From an a priori survey based on the methodology of Alvares et al. (2013), the average annual temperatures of the southern Brazil regions were $17^{\circ} \mathrm{C}$ in the southern portion and $19.5^{\circ} \mathrm{C}$ in the northern portion of the covered area. Thus, the evaluated regions could be divided into six environmental gradients separated at every $0.5^{\circ} \mathrm{C}$ of the average annual temperature, nested to the herds that belong to each environmental gradient defined. In the present study, these divisions were utilized as control variables and the genetic responses of the animal population were verified by various changes through the environmental gradients.

The statistical software SAS (SAS Institute Inc., 2013) was used to perform the data. Beyond the random additive genetic effect, the effects in the animal model included the fixed effects of contemporary group and calving age (18 to 42 months) as a covariate (linear and quadratic). The contemporary groups were created considering the interactions of herd-year-season, with four seasons of calving being considered (i.e., December to February, March to May, June to August, and September to November). The data were checked and records that included errors, insufficient information, animals of unknown parentage, progenies of bulls that only pertain to one herd, and contemporary groups containing fewer than three animals were removed.

Among the environmental gradients, herd connectivity was observed through the genetic presence of the bulls in at least three gradients. Since the animals were of unknown parentage, bulls that had been represented in less than three gradients or bulls that featured only once in the herd were removed from dataset. Finally, each environmental gradient contained included a minimum of 1,000 animals for analysis.

A random regression model was adopted to analyze GEI through reaction norms while assuming the residual variance to be heterogeneous in as many as eight classes of variance. Lastly, the fourth class was used because it presented the best fit under the Legendre polynomials. These polynomials were recently selected to promote the improved convergence of data in orthogonal regressions, as seen in the work of Schaeffer (2004). 
The Reaction Norms model, via random regression, is described as follows:

$$
y_{i j k}=I P+C G+\sum_{m=0 \beta m ø m}^{M}(T)+\sum_{m=0 \text { aimøm }}^{M}(T)+\varepsilon i j k
$$

where:

$y_{i j k}$ : phenotypic record for animal $\mathrm{i}(\mathrm{i}=1,2, \ldots, \mathrm{N})$, progeny of sire $\mathrm{j}(\mathrm{j}=1,2, \ldots, \mathrm{N})$, raised in $\mathrm{k}$ average temperature $(\mathrm{k}=1,2, \ldots, 6)$,

$I P$ : calving age as a covariate,

$C G$ : contemporary group effect,

$T$ : average temperature, where the herds were raised, as a function of the distribution along the year,

${ }_{m}(T): \mathrm{m}^{\text {th }}$ Legendre polynomial order,

$\beta_{m}$ : average regression coefficient of order $\mathrm{m}(\mathrm{m}=0,1,2, \ldots, \mathrm{M})$,

$\alpha_{i m}$ : random regression coefficient of order $\mathrm{m}$ for additive genetic effect of animal $\mathrm{i}$;

cijk: residual effect of animal i, progeny of sire j, raised in $\mathrm{k}$ average temperature.

The matrix representations are given as follows:

assuming that:

$$
y=X b+Z u+e
$$

$$
E=\left[\begin{array}{l}
y \\
b \\
u
\end{array}\right]=\left[\begin{array}{c}
X b \\
0 \\
0
\end{array}\right] \text { and } V\left[\begin{array}{l}
u \\
e
\end{array}\right]=\left[\begin{array}{cc}
K_{\text {rnoA }} & 0 \\
0 & R
\end{array}\right]
$$

where:

$y$ is the vector of observation,

$b$ is the vector of the fixed effects attributed to the contemporary group,

$u$ is the vector of random effects,

$e$ is the vector of the residual effects,

$X$ and $Z$ are the incidence matrices for the random and fixed effects, respectively,

$K_{r n}$ is the covariance matrix linked to the random effects for the model parameters of the reaction norms,

$A$ is the additive numerator relationship matrix,

$R$ is the residual variance matrix.

The constituents of additive genetic variance and estimates of direct heritability apply to the different environmental gradients according to the following models:

where:

$$
h^{2}=\frac{\sigma^{2} g a_{t}}{\sigma^{2} g a_{t}+\sigma^{2} e_{t}}
$$

$\mathrm{h}_{\mathrm{t}}^{2}$ is the direct heritability for the different production traits linked to each temperature gradient $\mathrm{t}$, 

ent,

$\sigma^{2} g_{a t}$ is the additive genetic variance ascribed to level $t$ of the temperature gradi-

$\sigma_{e t}^{2}$ is the estimate of residual variance attributed to level $t$ of the temperature gradient,

being,

$$
\sigma^{2} g_{a t}=\sigma_{a}^{2}+\sigma_{b}^{2}+\sigma_{a^{\prime} b}
$$

where:

$\sigma^{2}$ is the genetic variance estimate of the intercept component,

$\sigma_{b}^{2}$ is the slope estimate of the variance components of the reaction norms,

$\sigma_{a^{\prime} b}$ is the covariance estimate between the genetic effects of the intercept and slope.

Also, mixed models of analysis using the restricted maximum likelihood method (REML) were applied using WOMBAT ${ }^{\circledR}$ software (Meyer, 2007).

Additionally, the solutions of breeding values of all the animals (sires, dams and cows) were correlated among environmental gradients, using the PROC CORR procedure of the Statistical Analysis System (SAS Institute Inc., 2013), in order to verify the genetic correlations between the environmental gradients, allowing a better definition of the existence or absence of the genotype by environment interaction effect in the studied populations. For the regression of bulls through the gradients, the breeding value estimates at the t levels of the environmental gradient in the analysis of genetic variation were given by the weighted average of the breeding value of the daughters of each bull at each temperature level. A subset of data with information from the bulls present in all environmental gradients was formed to present a more reliable representation of the breeding value in each temperature gradient. For these analyses, 15 bulls with the highest number of daughters (494 daughters minimum) distributed by Southern Brazil were considered.

\section{Results}

The descriptive statistics for milk yield among Holstein cattle in Southern Brazil are presented in Table 1. Evidently, the gradients which showed greater numbers of animals $\left(17.0,17.5^{\circ} \mathrm{C}\right)$ also displayed a higher number of herds $(171$ and 103 , respectively) in the analyses. The highest production average for milk yield was at the $18.5^{\circ} \mathrm{C}$ temperature gradient, with a milk output up to $22.85 \%$ higher than the lower productive average among all the environmental gradients $\left(19.5^{\circ} \mathrm{C}\right)$. Regarding volume, the $18.5^{\circ} \mathrm{C}$ gradient revealed up to $803.52 \mathrm{~kg}$ of milk/animal/lactation more than the regions with $19.5^{\circ} \mathrm{C}$. Additionally, the coefficients of variation of the environmental gradients diverged between $21 \%$ for regions with temperatures around $18^{\circ} \mathrm{C}$ and $28 \%$ in regions experiencing temperatures of approximately $19.5^{\circ} \mathrm{C}$. 
Table 1. General descriptive statistics by temperature gradient for 305-d milk yield $(\mathrm{kg})$ in Holstein cattle of Southern Brazil

\begin{tabular}{lrrrrr|c|c|c}
\hline & $\mathrm{N}$ & $\mathrm{CG}$ & Herd & Mean & S.D. & Min. & Max. \\
\hline General & 67360 & 3355 & 398 & 8412.83 & 2012.08 & 613.16 & 18583.20 \\
Temperature $\left({ }^{\circ} \mathrm{C}\right)$ & & & & & & & \\
17.0 & 19194 & 1289 & 171 & 8280.48 & 2093.25 & 613.16 & 18583.24 \\
17.5 & 29121 & 1100 & 103 & 8602.39 & 2028.41 & 731.54 & 17882.07 \\
18.0 & 1956 & 86 & 8 & 8664.71 & 1800.10 & 1489.00 & 15729.18 \\
18.5 & 1140 & 91 & 21 & 8801.86 & 1963.88 & 1137.36 & 13411.34 \\
19.0 & 14402 & 588 & 49 & 8129.20 & 1932.88 & 623.00 & 14785.93 \\
19.5 & 1547 & 201 & 46 & 7998.34 & 2254.00 & 1601.02 & 16256.54 \\
\hline
\end{tabular}

$\mathrm{N}=$ number of animals considered in the analyses.

$\mathrm{CG}=$ contemporary groups.

Herd $=$ number of herds evaluated.

S.D. $=$ standard deviation.

Min $=$ minimum value of production .

Max = maximum value of production.

Genetic, environmental, and phenotypic variances, as well as heritabilities and their standard errors, are presented in Table 2. The highest level of phenotypic variance was observed for $18^{\circ} \mathrm{C}$, primarily due to the high residual variance presented. However, the high residual variance obtained in this gradient was not sufficient to exceedingly reduce heritability since the additive genetic variance was also high. The lowest additive genetic variance was represented at the $17^{\circ} \mathrm{C}$ gradient, which also registered the lowest heritability among the gradients (0.18). A decrease in the heritabilities was evident after $17.5^{\circ} \mathrm{C}$ gradient, demonstrating a tendency to reduction of this genetic parameter according to the elevation of the temperature.

Table 2. Values of phenotypic variance $\left(\sigma^{2} \mathrm{p}\right)$, residual variance $\left(\sigma^{2} \mathrm{e}\right)$, additive genetic variance $\left(\sigma^{2} \mathrm{a}\right)$, heritability $\left(\mathrm{h}^{2}\right)$ and standard error $\left(\sigma_{\mathrm{e}}^{\wedge}\right)$ for the different temperature gradients of the Holstein animals in Southern Brazil, for the 305-d milk yield $(\mathrm{kg})$

\begin{tabular}{l|c|c|c|c|c}
\hline \multicolumn{1}{c|}{ Temperature $\left({ }^{\circ} \mathrm{C}\right)$} & $\sigma_{\mathrm{p}}^{2}$ & $\sigma^{2}{ }_{\mathrm{e}}$ & $\sigma^{2}{ }_{\mathrm{a}}$ & $\mathrm{h}^{2}$ & $\sigma_{\mathrm{e}}$ \\
\hline 17.0 & 2275340.00 & 1865277.00 & 410063.00 & 0.18 & 0.009 \\
17.5 & 2527070.00 & 1941364.00 & 585706.00 & 0.23 & 0.002 \\
18.0 & 2811810.00 & 2202702.00 & 609108.00 & 0.22 & 0.002 \\
18.5 & 2423060.00 & 1882607.00 & 540453.00 & 0.22 & 0.000 \\
19.0 & 2343550.00 & 1869587.00 & 473963.00 & 0.20 & 0.003 \\
19.5 & 2452830.00 & 2001598.00 & 451232.00 & 0.18 & 0.002 \\
\hline
\end{tabular}

The correlations between environmental gradients used to verify the presence of a genotype by environment interaction are presented in Figure 1. All of the gradients registered correlations exceeding 0.800 . Figure 2 presents the breeding values of the 15 most representative bulls in the state of Paraná and their interactions with a rise in environmental temperature. Notably, distinct responses were observed as environmental gradients changed. In certain cases, bulls showed a breeding value increase 
of up to $289 \mathrm{~kg}$ of milk compared to different gradient regions. Animals exhibiting mean values that were already lower than the genetic base (value of 0 ) revealed the highest variation in breeding values. Moreover, animals with higher breeding values compared to those around or below the genetic base of the population demonstrated lower variation in breeding values when environmental temperature increased. It is noteworthy that the repositioning of bulls during the advancement of the environmental gradient was punctual and revealed only a few alterations in position among the bulls.

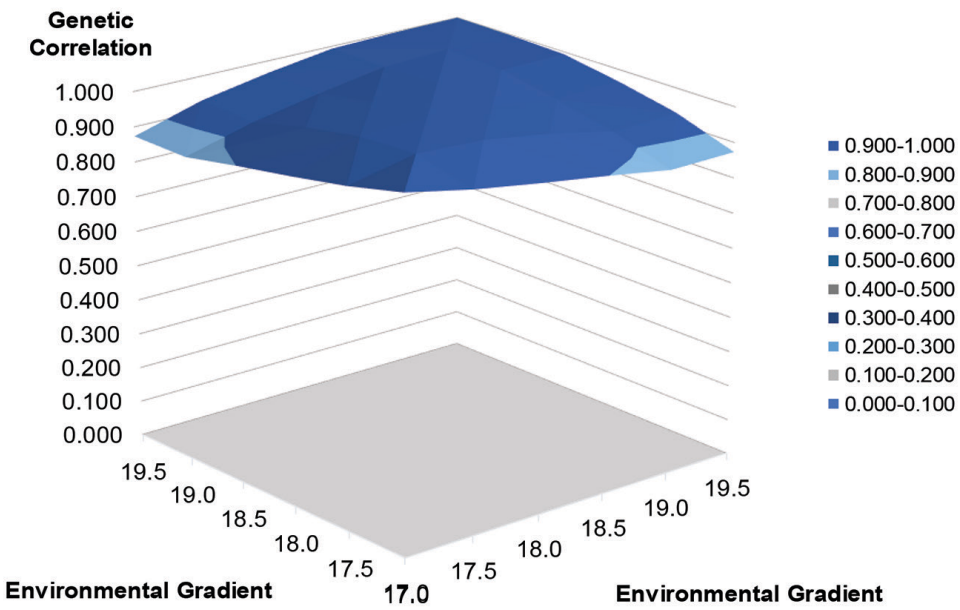

Figure 1. Genetic correlations between the environmental temperature gradients for 305-d milk yield $(\mathrm{kg})$ in the Holstein cattle of Southern Brazil

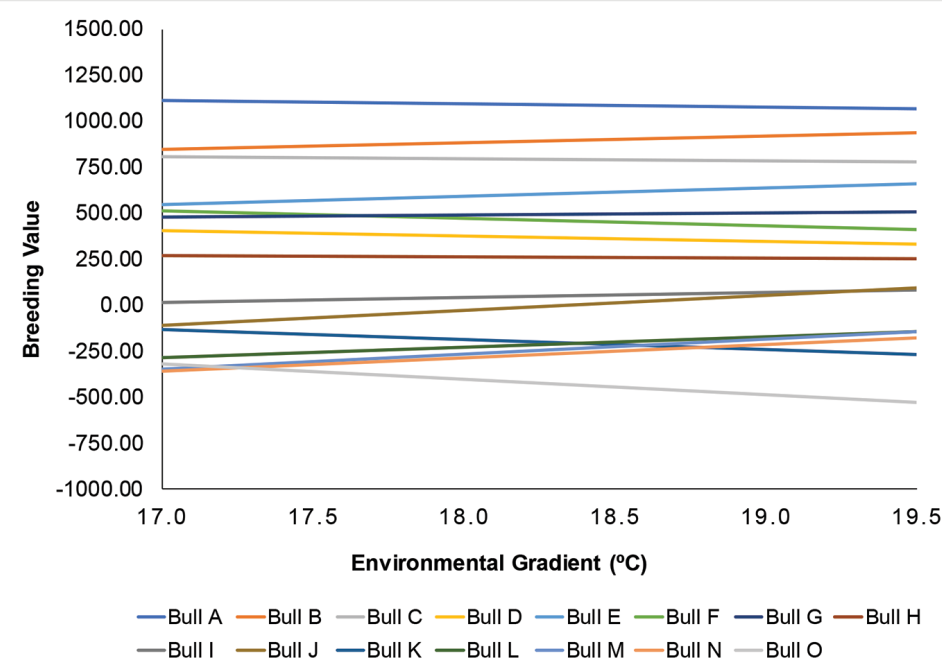

Figure 2. Reaction norms for 305-d milk yield (kg) using the pattern of breeding values (daughters' average) of the 15 most representative bulls utilized in Southern Brazil region 


\section{Discussion}

Average milk production in the present study was $8412.83 \mathrm{~kg}$ milk/animal/year, which exceeds the previously reported finding of $1709 \mathrm{~kg}$ milk/animal/year reported for milk production in Brazil (IBGE, 2016), thus confirming the high productivity in Southern herds. The annual milk production achieved in the present work is nearly equal to the production of the high-yielding countries, such as the United States (Hadrich et al., 2018) or Canada (Do et al., 2018), which emphasizes the high productive potential of these animals. These results suggest that, even with the heterogeneity of production in Southern Brazil herds indicated by Telles et al. (2017), the studied regions continue to provide high yields at the different temperatures assessed.

Another noteworthy observation was that a greater number of herds and higher numbers of animals per herd were recorded in the regions close to $17^{\circ} \mathrm{C}$. This is directly contrary to what was observed toward the northern portion of the evaluated regions, where the number of herds was fewer with a lower number of animals per herd. This fact is related to the dairy basins being found in greater concentration toward the south of the analyzed region (Paula et al., 2009), which has a long history of dairy farming as a traditional and principal livestock activity. Therefore, it is true that greater investments and higher yields can occur in these milk basins since dairy farming represents the main economic activity.

Upon analyzing the data, a drop in the production was noted after the temperature increased to a certain degree (above gradient $19.0^{\circ} \mathrm{C}$ ). Such variation implies that a rise in temperature causes milk production to decline. This proposition was supported by Yano et al. (2014), who confirmed that animals with high productive potential are more sensitive to heat; therefore, their production averages decrease when they become exposed to higher temperatures.

The heritability estimates were mostly moderate, which is consistent with earlier studies conducted on Southern Brazil herds (Moreira et al., 2019; Paula et al., 2008, 2009). The only exceptions noted for heritability were specifically for temperatures of $17^{\circ} \mathrm{C}$ and $19.5^{\circ} \mathrm{C}$, which were low in magnitude.

After $17.5^{\circ} \mathrm{C}$, the heritability estimates declined as the regional temperature escalated. Similar behavior was also reported in research on the Holstein breed in Spanish (Carabaño et al., 2014) and Belgian herds (Hammami et al., 2015), further supporting the notion that temperature could affect gene expression for the milk trait. Therefore, the presence of variation in heritability can result in different selection responses according to the different environments considered (Bignardi et al., 2015).

Based on the variances (as presented in Table 2), a balance between genetic variance is evident, which implies that the animals exhibited some manner of similar genetic manifestations at the different temperature gradients observed. Therefore, differences in heritability in response to increased temperature can be supported by variation produced in the environmental factors inducing variation in heritability. The Canadian (Loker et al., 2012) and United States dairy herds (Abdalla et al., 2016) exhibited higher heritability when compared to the dairy herds of Brazil. This could be explained by the exposure of the animals to the selection process, thus 
facilitating a reduction in the residual effect, which results in increased heritability estimates over time.

Based on the criterion reported by Robertson (1959), the genetic correlations between different environmental gradients were verified as being above 0.80 (Figure 1), thus suggesting an absence of GEI at all gradients assessed. In this study, the high estimates of genetic correlation identified, which revealed that milk yield is similarly expressed in all studied regions, demonstrated no significant genetic alterations resulting from regional temperature increase among dairy herds of Southern Brazil. The low correlation - and thus significant GEI effect -could be anticipated if the variations in mean temperature were higher between regions, over longer durations (Bohmanova et al., 2008), or at different latitudes in the evaluations (Ismael et al., 2016). However, in Southern Brazil, even the prevalent climatic differences were insufficient to result in a negative impact on breeding values along different gradients in the expression of milk yield across the Holstein cattle population.

Although the correlations revealed no important genotype by environment interaction effect, minimal changes were noted in the average breeding values of sires in response to increased temperature (see Figure 2). In general, the breeding values were similar as temperature increased, suggesting that no relevant impact on the genetic response of the progenies will occur, despite the environment that the animals will be raised, considering the evaluated regions.

The present study revealed that, despite the rise in temperature, few animals (particularly those with higher breeding values) demonstrated genetic persistence. Moreover, milk yield was unaffected by alterations in regional temperature, thus distinguishing these animals as being robust for this trait (van der Veen et al., 2009). Therefore, even under conditions of temperature variation, similar genetic gains are possible throughout the evaluated region. However, animals that showed low breeding values revealed breeding values responses that fluctuated according to increased temperature, thus identifying them as animals known as "plastic" (Bohlouli and Alijani, 2012) for the milk trait.

Changes induced by temperature increase could not be related only to alterations in the genetic constitution of the animals; still, these changes could be associated to neuroendocrine responses stimulated from a rise in temperature that influences the transcription of the genes controlling milk yield (Dingemanse and Wolf, 2013). For instance, small changes were visibly confirmed in the case of a few bulls assessed in the present study. For example, in response to the temperature increase, bull " $\mathrm{O}$ " revealed a lower breeding value, while bull "J" demonstrated a remarkable increase in breeding value; in these specific cases, their genetic responses require monitoring in accordance with the climatic variations to which their daughters will be exposed.

Although such examples were encountered, the reclassification of bulls was punctual during the temperature gradient period. This was anticipated since no significant interaction between genotype and temperature was noted (Pegolo et al., 2011). The repositioning mostly occurred after the $18.5^{\circ} \mathrm{C}$ environment and was not connected (in part) to lowering the breeding value of bulls; instead, it was connected to increased breeding value in response to temperature rise. In this case, we highlight that bull "G", which occupied sixth place in the ranking for the general classification 
of genetic merit for milk yield in the $17^{\circ} \mathrm{C}$ gradient, moved to fifth place in the $19.5^{\circ} \mathrm{C}$ gradient. Another example was bull "J", which dropped below the average relative to the genetic base of the population at the $17^{\circ} \mathrm{C}$ gradient; however, when temperatures rose, its individual merit also grew, eventually resulting in him becoming one of the top nine bulls at the $19.5^{\circ} \mathrm{C}$ gradient. In these cases, if these bulls were to be utilized in different regions, they would require constant monitoring due to their performance potentially becoming altered depending on where their progenies would be raised.

\section{Conclusion}

No significant genotype by environment interaction could be observed with regional temperature increase for milk yield in the Holstein cattle of Southern Brazil. Breeding values were only altered in a few bulls in response to temperature increases. These results indicate that it is not necessary to consider temperature as an effect in models of genetic evaluation for Holstein cattle of the studied region.

\section{Acknowledgments}

The authors thank the Paraná Holstein Breeders Association (APCBRH) for providing the pedigree and phenotypic data. Thanks to National Council for Scientific and Technological Development (CNPq), National Council for the Improvement of Higher Education (CAPES) and Araucária Foundation (Fundação Araucária) for granting the scholarships and the funds to develop this research.

\section{References}

A b d a 11 a E.A., We i g e 1 K.A., B y re m T.M., R o s a G.J.M. (2016). Short communication: Genetic correlation of bovine leukosis incidence with somatic cell score and milk yield in a US Holstein population. J. Dairy Sci., 99: 2005-2009.

A 1 Reyad M., A bid Has an S.M., Eli as U.M., H abib R., Harun-ur-R a sh id M. (2016). Effect of heat stress on milk production and its composition of Holstein Friesian crossbred dairy cows. Asian J. Med. Biol. Res., 2: 190-195.

A 1 vares C.A., S t a p e J.L., S e n t e 1 h a s P.C., D e Moraes Gon çalves J.L., S p a rovek G. (2013). Köppen's climate classification map for Brazil. Meteorol. Z., 22: 711-728.

B en ni S., P a s te 11 M., B on ora F., Tas s inari P., Torregg i a i D. (2020). A generalised additive model to characterise dairy cows' responses to heat stress. Animal, 14: 418-424.

Bignardi A.B., Faro L.E., Pereira R.J., Ayres D.R., Machado P.F., Albuquerque L.G.D., S a n tan a Juni or M.L. (2015). Reaction norm model to describe environmental sensitivity across first lactation in dairy cattle under tropical conditions. Trop. Anim. Health Pro., 47: 1405-1410.

B ohlouli M., Alijani S. (2012). Genotype by environment interaction for milk production traits in Iranian Holstein dairy cattle using random regression model. Livest. Res. Rural Dev., 24: 7-12.

Bohmanova J., Misztal I., Tsuruta S., Norman H.D., Lawlor T.J. (2008). Short communication: Genotype by environment interaction due to heat stress. J. Dairy Sci., 91: 840-846.

C a rabaño M.J., B a chagha K., R a món M., Día z C. (2014). Modeling heat stress effect on Holstein cows under hot and dry conditions: Selection tools. J. Dairy Sci., 97: 7889-7904.

Cotor G., Gâjâilă G., Vitel aru A.B., Ghiţă M., B ră s la şu C. (2015). The effect of environmental temperature variation, on milk yield and composition, in dairy cows. J. Biotechnol., 208: S39.

D in g e m a n s e N.J., Wo $1 \mathrm{f}$ M. (2013). Between-individual differences in behavioural plasticity within populations: causes and consequences. Anim. Behav., 85: 1031-1039. 
Do D.N., Fleming A., Schenkel F.S., Miglior F., Zhao X., Ibeagha-Awemu E.M. (2018). Genetic parameters of milk cholesterol content in Holstein cattle. Can. J. Anim. Sci., 98: 714-722.

F a l c o n e r D.S. (1952). The problem of environment and selection. Am. Nat., 86: 293-298.

Hadrich J.C., Wolf C.A., L o mbard J., D ol a k T.M. (2018). Estimating milk yield and value losses from increased somatic cell count on US dairy farms. J. Dairy Sci., 101: 3588-3596.

Ha m m a mi H., Rekik B., Gengler N. (2009). Genotype by environment interaction in dairy cattle. Biotechnol. Agron. Soc. Eviron., 13: 155-164.

Hammami H., Vandenplas J., Vanrobays M.L., Rekik B., Bastin C., Gengler N. (2015). Genetic analysis of heat stress effects on yield traits, udder health, and fatty acids of Walloon Holstein cows. J. Dairy Sci., 98: 4956-4968.

H a y E.H., R o berts A. (2018). Genotype $\times$ prenatal and post-weaning nutritional environment interaction in a composite beef cattle breed using reaction norms and a multi-trait model. J. Anim. Sci., 96: 444-453.

Instituto Brasileiro de Estatística e Geografia - IBGE (2016). Produção pecuária municipal. Decision Support Systems, 44: 1-51.

I s ma e 1 A., Strandberg E., B erglund B., Kargo M., Fogh A., Løvendahl P. (2016). Genotype by environment interaction for the interval from calving to first insemination with regard to calving month and geographic location in Holstein cows in Denmark and Sweden. J. Dairy Sci., 99: 5498-5507.

Komisarek J., Kolenda M. (2016). The effect of DGAT1 polymorphism on milk production traits in dairy cows depending on environmental temperature. Turk J. Vet. Anim. Sci., 40: $251-254$.

Loker S., B a stin C., Miglior F., S e wa le m A., S cha effer L.R., J a m ro zi k J., A li A., O s b o rn e V. (2012). Genetic and environmental relationships between body condition score and milk production traits in Canadian Holsteins. J. Dairy Sci., 95: 410-419.

M e y e r K. (2007). WOMBAT - A tool for mixed model analyses in quantitative genetics by restricted maximum likelihood (REML). J. Zhejiang Univ. Sci. B., 8: 815-821.

Mirand a J.A., Pires A.V., A breu L.R.A., Mota L.F.M., S ilva M.A., B on a fé C.M., Li m a H.J.D., Martin s P.G.M.A. (2016). Sensitivity of breeding values for carcass traits of meattype quail to changes in dietary (methionine + cystine):lysine ratio using reaction norm models. J. Anim. Breed Genet., 133: 463-475.

Mor e ir a R.P., P in to L.F.B., Vallo to A.A., P e dros a V.B. (2019). Evaluation of genotype by environment interactions on milk production traits of Holstein cows in Southern Brazil. Asian-Australas. J. Anim. Sci., 32: 459-466.

Paula M.C.D., Martins E.N., Otávi o L., Antonio C., Oliveira L.D., Valotto A.A., G a s p a r i n o E. (2008). Estimativas de parâmetros genéticos para produção e composição do leite de vacas da raça Holandesa no estado do Paraná. R. Bras. Zootec., 37: 824-828.

Paula M.C.D., Martins E.N., Otávio L., Antonio C., Oliveira L.D., Valotto A.A., R i b a s N.P. (2009). Interação genótipo $\times$ ambiente para produção de leite de bovinos da raça Holandesa entre bacias leiteiras no estado do Paraná. R. Bras. Zootec., 38: 467-473.

P e g o lo N.T., Albu que rque L.G., Lôbo R.B., d e Oliveir a H.N. (2011). Effects of sex and age on genotype $\times$ environment interaction for beef cattle body weight studied using reaction norm models. J. Anim. Sci., 89: 3410-3425.

R a u w W.M., G o m e z - R a y a L. (2015). Genotype by environment interaction and breeding for robustness in livestock. Front Genet., 6: 1-15.

R oberts on A. (1959). Experimental design in the evaluation of genetic parameters. Biometrics, 15: $219-226$.

R o b e rt s o n A. (1960). Experimental design on the measurement of heritabilities and genetic correlations. In: Biometrical Genetics, Kempthorne O. (ed.). Pergamon Press, Oxford, pp. 101-106.

SAS Institute Inc. (2013). SAS 9.1.3 Help and Documentation. Cary: ADABAS.

$\mathrm{S} \mathrm{c}$ h a e ffer L.R. (2004). Application of random regression models in animal breeding. Livest. Prod. Sci., 86: 35-45.

Secretaria de Estado da Agricultura e do Abastecimento - SEAB. (2000). Caracterização da Bovinocultura de Leite no Estado do Paraná. 80. 
Streit M., Reinhardt F., Thaller G., Bennewitz J. (2012). Reaction norms and genotype-by-environment interaction in the German Holstein dairy cattle. J. Anim. Breed Genet., 129: 380-389.

Telle s T.S., B a c c h i M.D., Sh i mi zu J. (2017). Distribuição espacial de microrregiões especializadas na produção de leite. Semina: Ciênc. Agrár., 38: 443-453.

Tiezzi F., de los Campos G., Parker Gaddis K.L., Maltec c a C. (2017). Genotype by environment (climate) interaction improves genomic prediction for production traits in US Holstein cattle. J. Dairy Sci., 100: 2042-2056.

van der Veen A.A., Napel J., O osting S.J., B on ts e ma J., Zijp p A.J.V.D. (2009). Robust performance: principles and potential applications in livestock production systems. EFITA, 1: $173-180$.

Yano M., Shimadzu H., Endo T. (2014). Modelling temperature effects on milk production: a study on Holstein cows at a Japanese farm. SpringerPlus, 3: 1-11.

Received: 28 X 2019

Accepted: 10 III 2020 